\title{
سوسيولوجيا الإسلام في الفكر الفلدوني -"قراءة في سوسيولوجيا الدين"
}

\section{أ.د. يوسف عناد زامل/ كلية القانوز/ جامعة واسط م.د. أحمد باسيز أحمد / كلية الآداب / جامعة واسط}

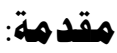

كان ابن خلدون عقلية واضحة كلها ضوء، وان ضـو هه العقلي يمزق كل غموض، انه من الأتقياء ومن كبـار

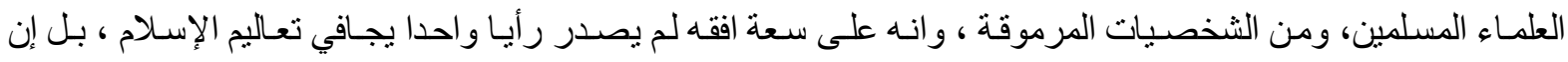

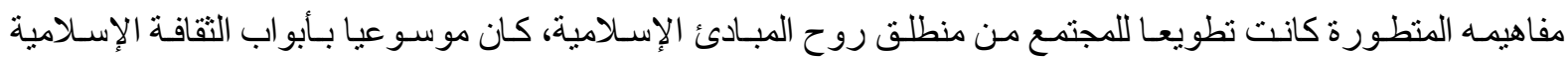

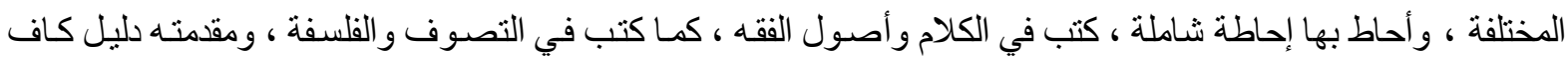
على علمهـ الواسـع واطلاعـه الغزيـر .وجعل ابن خلدون العرب محور تفكيـره، وأعطـاهم الدور الأول في الإسـلام فهم

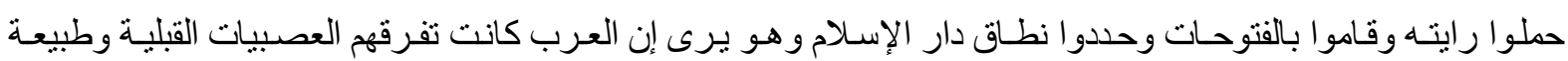

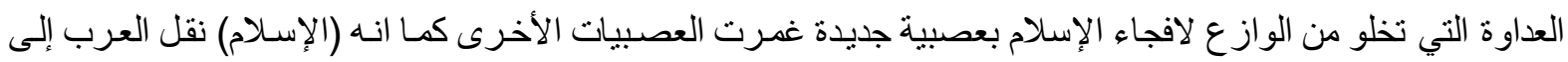

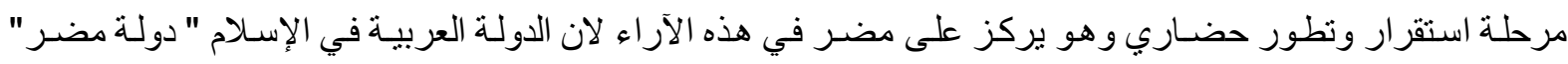

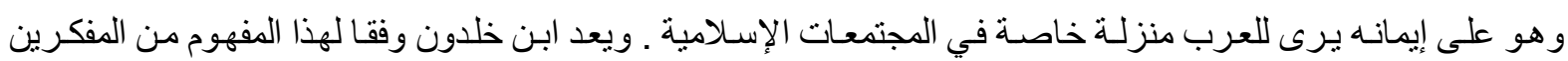

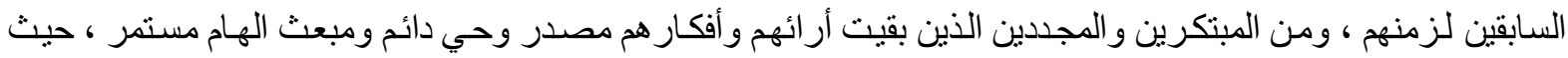

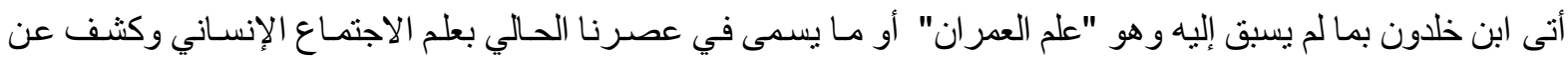

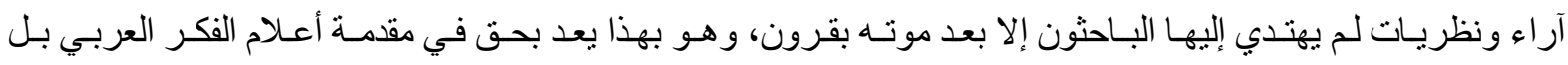

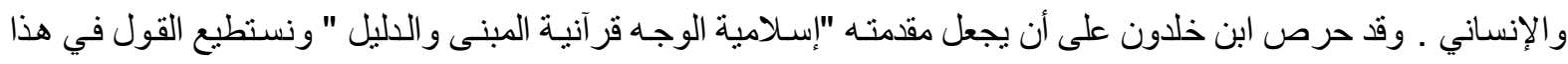

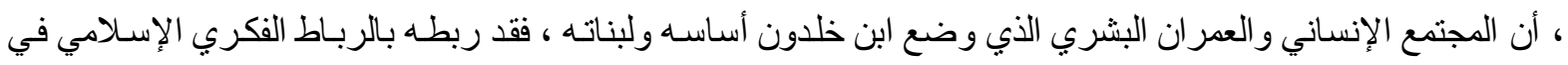

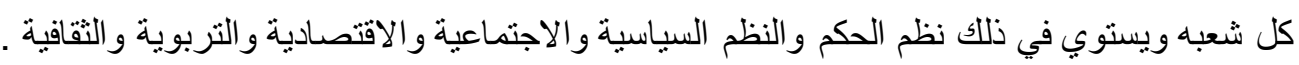
ويعد ابن خلدون واحدا من أولئلك الإعـلام الذين تربوا في أحضـان الإسـلام وتعاليمسه و الذين كانت لدعوتـهـ

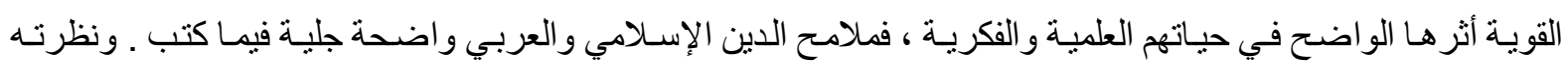

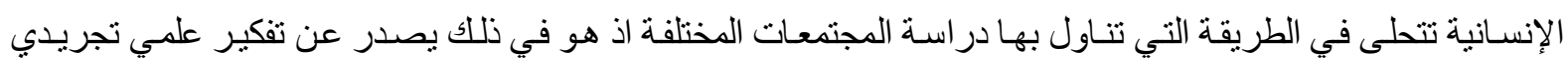
أصيل وفقه إسلامي إنساني صحيح ، وهو في الوقت نفسـه أنشاد للعرب كأصحاب رسـالة دعوة ، ولو لا مبادئ هذا الدين

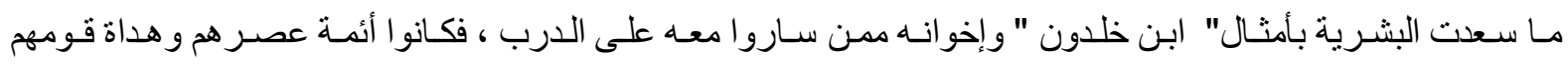

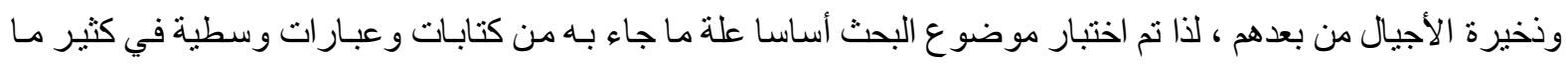

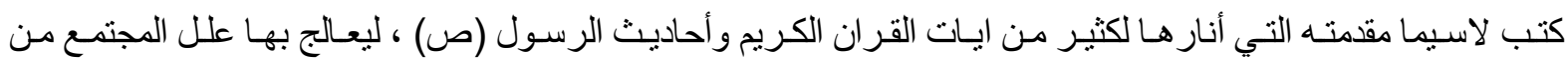

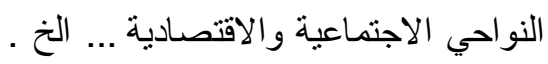
من المؤكد ان "ابن خلدون" نتـاج بييتته وحصـاد مجتمعـه ونتـاج ثقافته ، فقد كـان عالمـا من علمـاء المسلمين

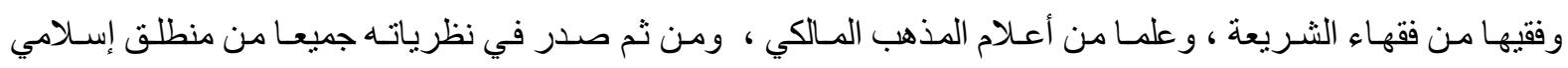

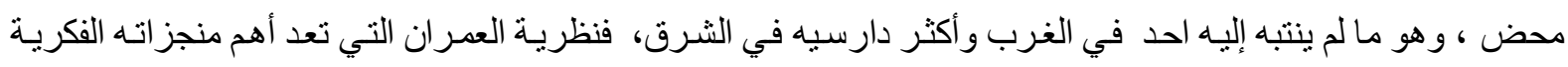

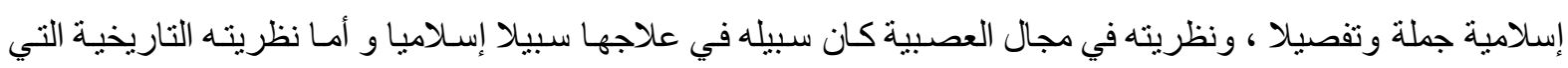

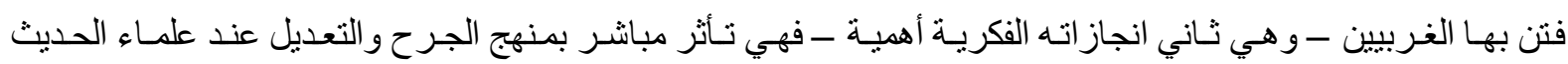

\section{$-\boldsymbol{r} \cdot \varepsilon$}


الثريف ، لقد اعتمد ابن خلدون الأسس الإسلامية وهو يقدم نظرياته ، ونظسام الحكم الذي رآه مناسبا للعمران ، وهو نظسام الخلافة الإسلامية وتبني ابن خلدون لعناصر كتاب طاهر ابن الحسين لولده ، حبن و لاه المسأمون مصر تمثنل جوهر النظـام

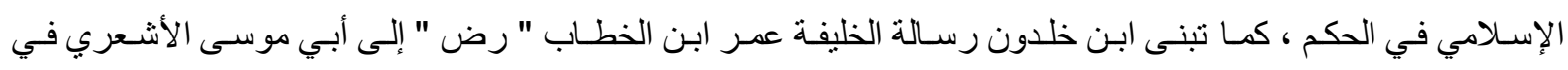

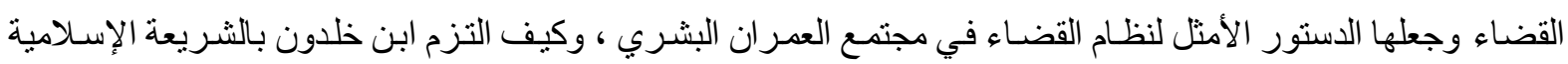

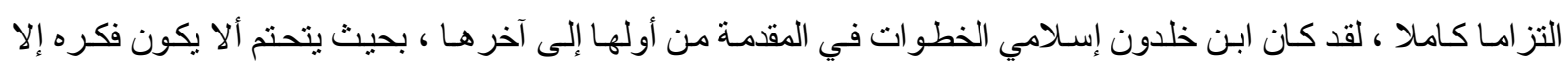

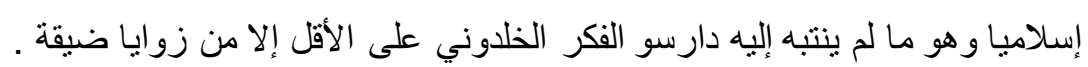

ومسادام رأس الدولـة في العـران الخلدوني هو الإمـام أو الخليفة فإنها عنده وظيفة دينية سياسية اجتماعيـة ،

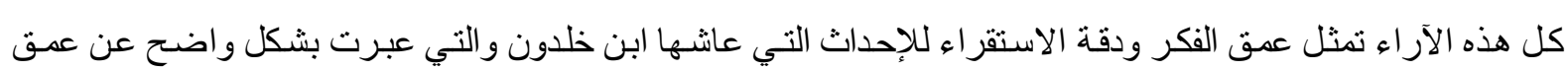

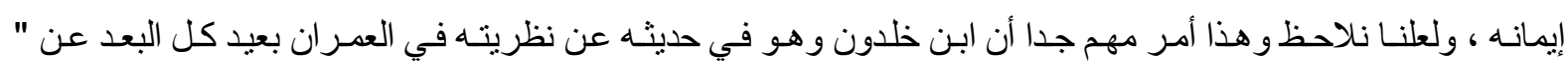

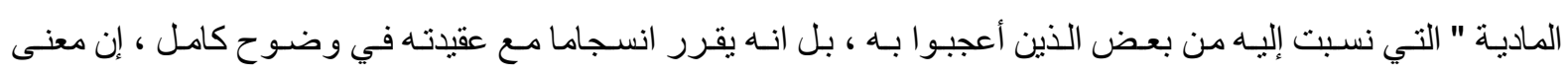

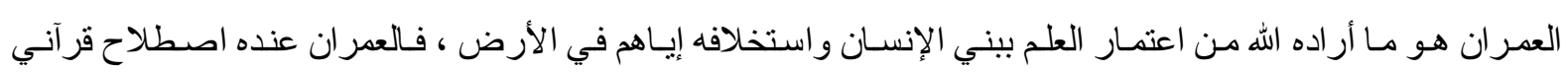

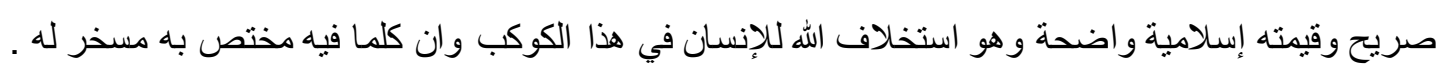
وباختصار يمكن القول : إن ابن خلدون "فقيه أصسولي مجتهد" وهو أستاذ كانت دروسـه أصـا في التفسير و الحديث و الفقه وقد حرص في كل أفكار ها التي عرفت بالنظريـات فيمـا بعد على أن يدعم كلا منهمـا بمـا يؤكد إسـلاميتها

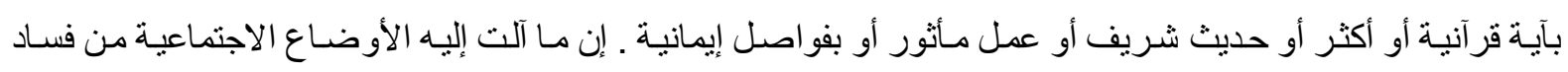
و انحطاط في عصر ابن خلدون جعله ينصرف لدر اسة المجتمع يطلب من الدروس والعبر التي شـانها أن تسـاعده على فهم

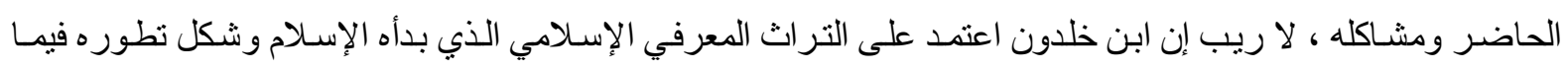

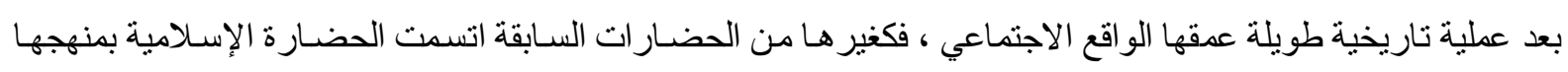

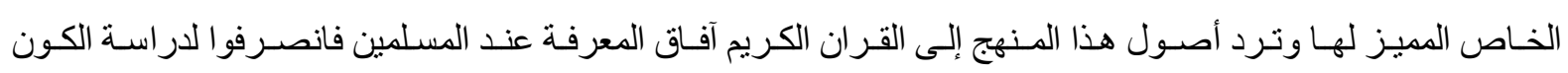

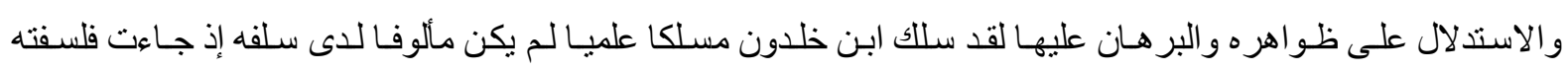

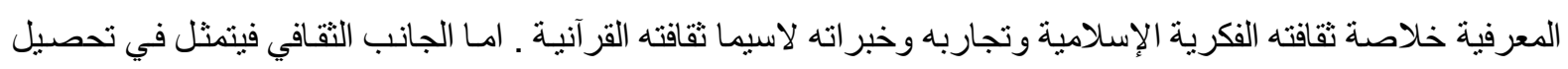

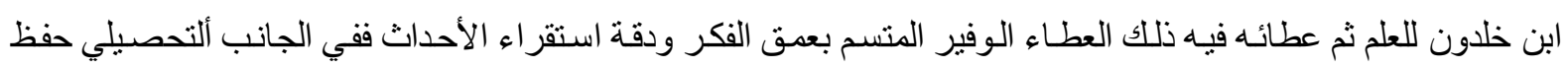

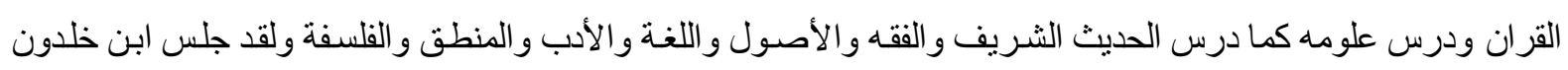
للتدريس في أكثر البلدان التي حل بها وكانت المسـاجد الكبرى و المدارس الثهيرة مقر الحلقات دروسـه كمـا تولى التدريس في الأزهر الثريف واستطاع من خلال ذلك إن أفكاره إلى عدد كبير من الدارسين المصريين وغير هم من الو افدين إلى ولى

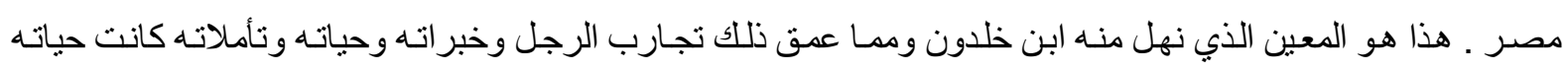

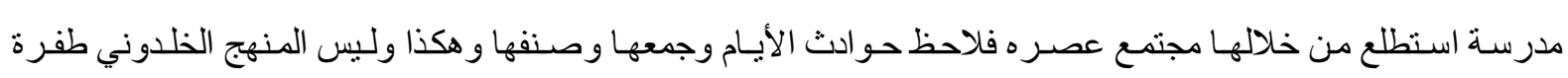
بقرر ما هو حصاد التراث المعرفي الإسلامي لكنه يشكل بحق ثورة في تاريخ فلسفة المعرفة .

سنتناول في هذا البحث موضو عا إسلاميا بحتا ولم نعتمد مصادر كثيرة في ذلك ، لأننا سنقوم بتحليل الفكر

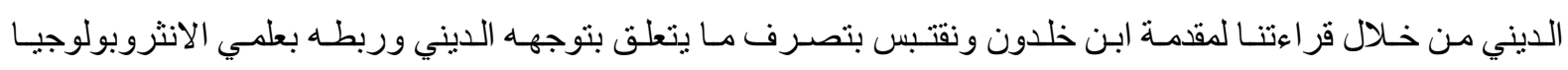

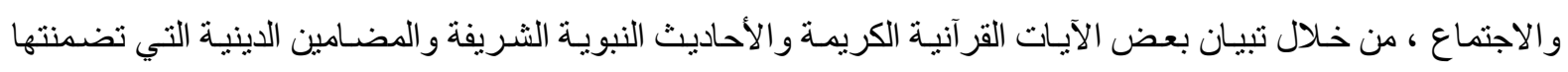

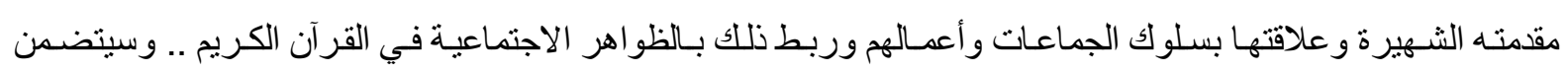

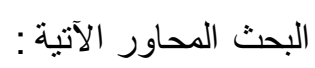

\section{- r. O}




\section{أبن خلدون والتزاث الإسلاهي .}

أعتمد أبن خلدون على التراث المعرفي الإسـلامي الذي بـأه الإسـلام ، والسـبب في ذللك هـو مـا آلت إليـه

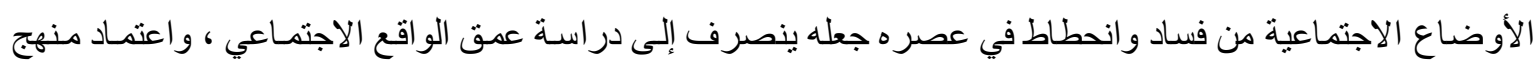

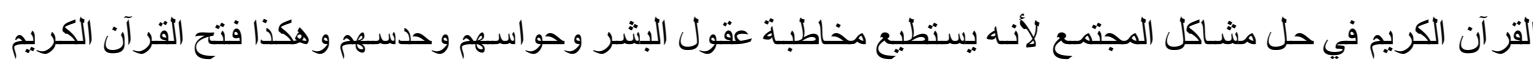

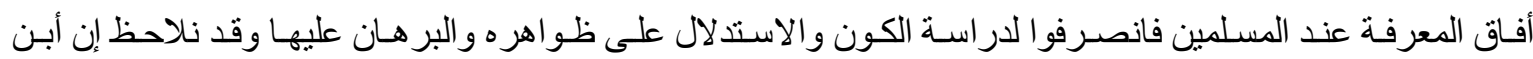

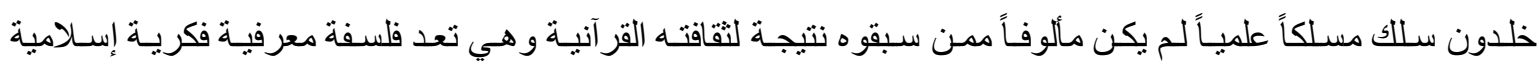

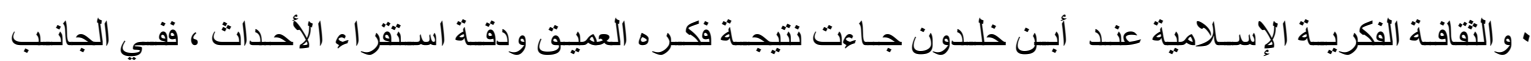

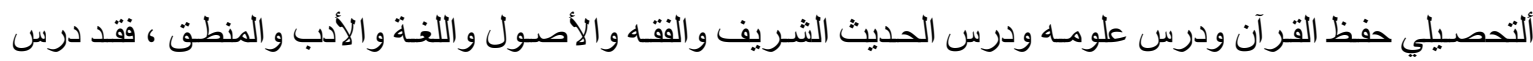

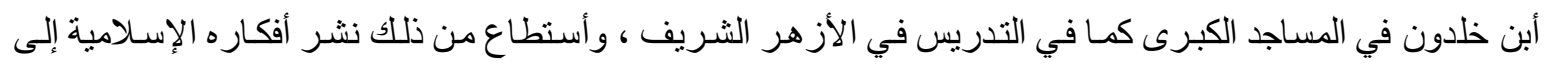
عدد كبير من الدارسين المصريين وغيرهم وفي أكثر البلدان التي ظلَ بها ـ و وإن أصل المعرفة الإسـلامية عند أبن

خلدون تأتي من اعتماده مصادر أساسية معرفية هي (1):

(الحقيقة إن فكر أبن الخلدوني الإسـلامي مقدمته تـدين بالجانب الأكبر من روحهـا مستوحاة من القـرآن الكريم : بل هو مدين للقرآن على حد كبير حتى في أحكامسه على الأخـلاق والطبائع ، إن القرآن الكريم بقصصسه على حياة

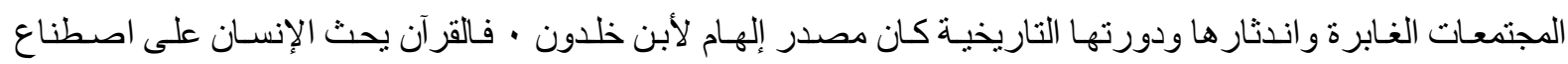

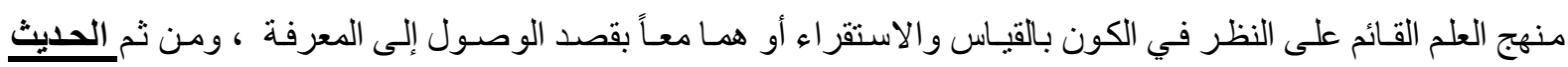

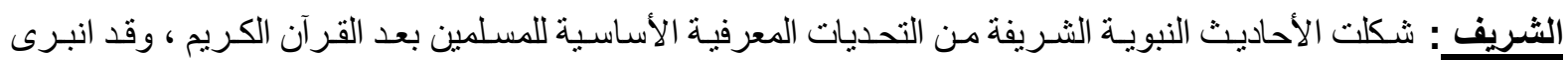
الققهاء لوضع قو اعد لجمع الحديث في الصدق والاعتمـاد على اللفظ دون المعنى ، وقد اعتبرت الأحاديث النبويـة الثرريفة

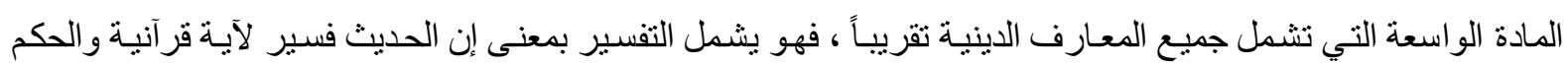

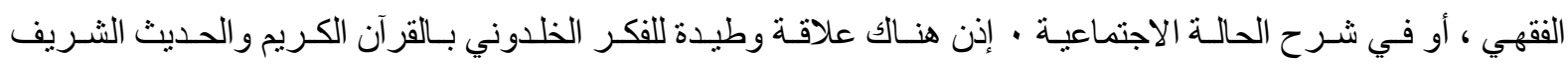

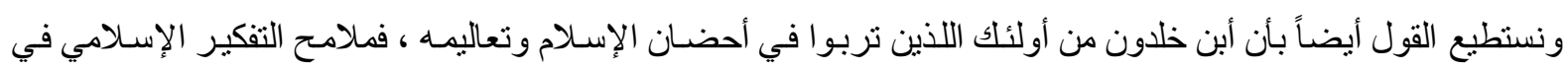
كتبه ونظرياته تتجلى في طريقته التي تنـاول فيها در اسـة المجتمعات المختلفة وفي مقدمته الثـهيرة " كتاب العبر والمبتدأ

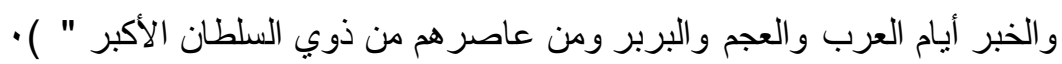

\section{هفهوم القرآن الكريم في الفكر الخلدوني .}

إن مفهوم القرآن الكريم عند أبن خلدون هو مفهوم شرعي و علمي معـاً هو : " كـلام الله المنزل على نبيـه حمحة

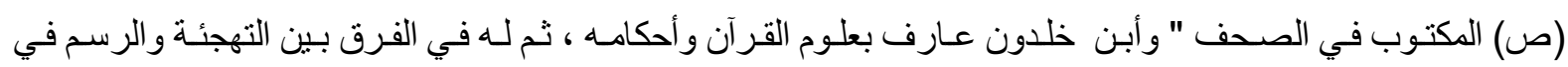

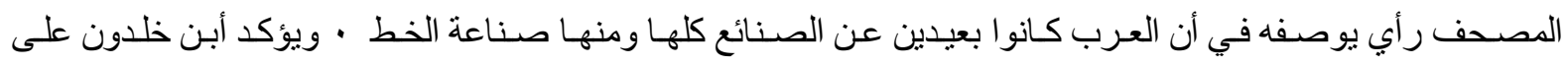

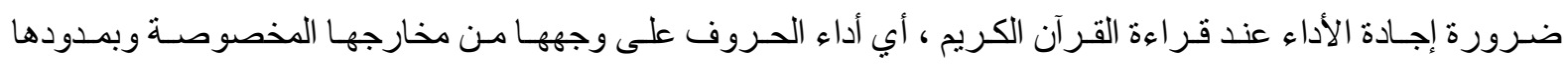

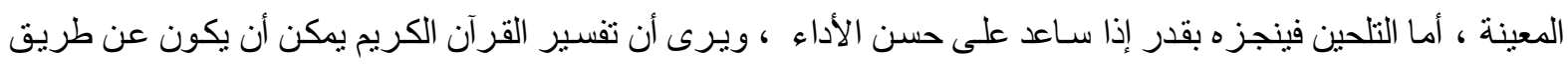

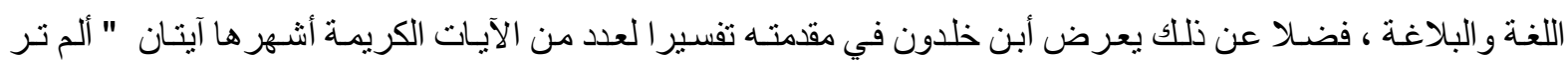

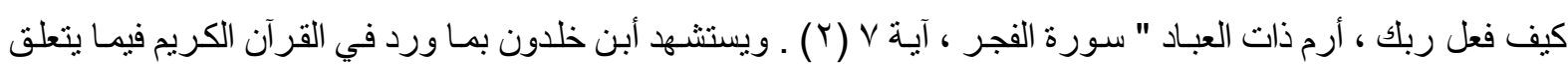

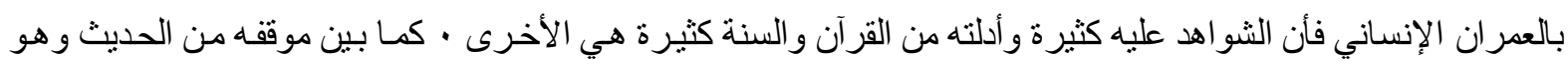

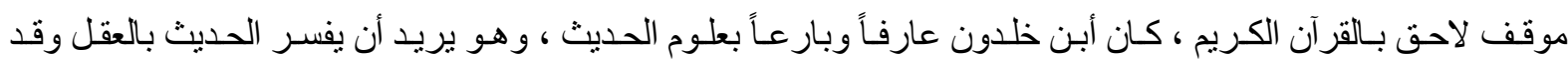

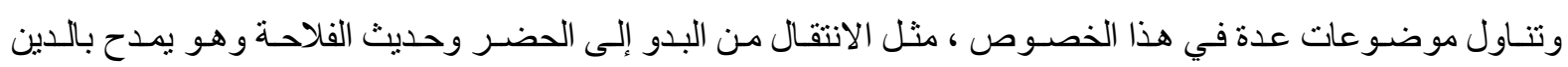


و التقوى ويفتخر بذلك كله · فقي ديباجة مقدمته يذكر تقديم كتابه إلى السلطان فـارس عبد العزيز (سلطان المغرب) فيقول . .

" . . . من ملوك بني مرين اللذين جددوا الدين ونهجوا السبيل إلى المهندين ، ومحوا آثار البغاة والمفسدين )" (بآ).

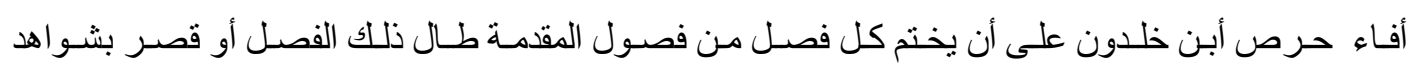

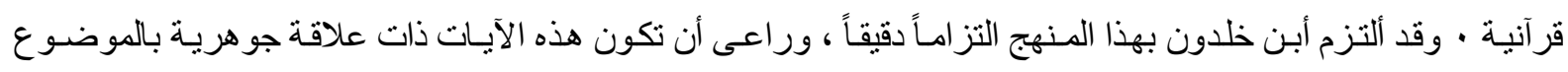

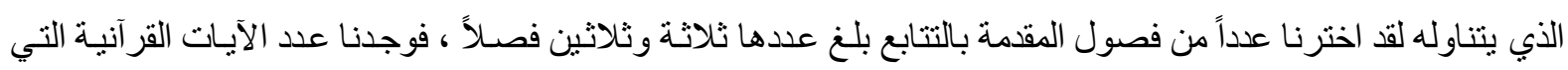

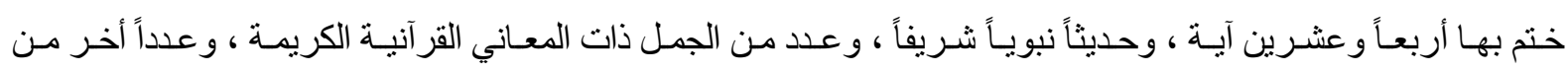

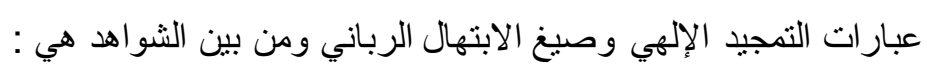

* في خاتمة استفتاح المقدة يشير إلى قوله تعالى " حسبنا الله ونعم الوكيل " سورة آل عمران آية بلا .

* في أن البدو أقرب إلى الثجاعة والأصالة بقوله " الله يخلق ما يشاء " سورة آل عمران آية Vع .

* في البيت والشرف والأصلالة ، يختمه بقوله تعالى " و الله بكل شيء عليم " سورة النور آية هب .

* في الرئاسة على أهل العصبية بقوله تعالى " و الله عالم الغيب والثهادة " سورة الأنعام آية بل .

* فصل في حقيقة النبوة والكهانة والرؤيا يختمه بقوله تعالى " و الله يعلم وانتم لا تعلمون " سورة النور آية 19 * فصل في اثر الهواء في أخـلاق البشـر يختمه بقوله تعـالى "الله يهدي من يثـاء إلى صـر اط مستقيم" سورة البقرة آيـة

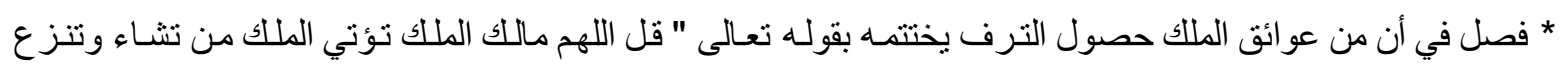

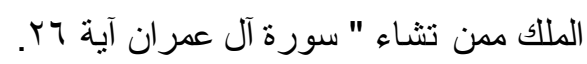

* فصل في اختلاف أحوال العمر ان في الخصب والجوع يختتمهه بقوله تعـالى " انهه بكل شيء محبط " سورة فصلت آيـة

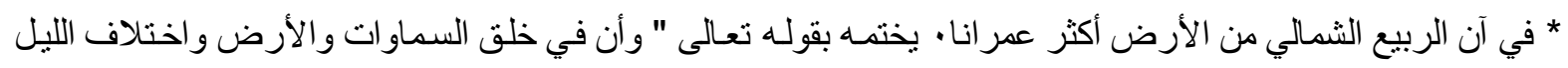

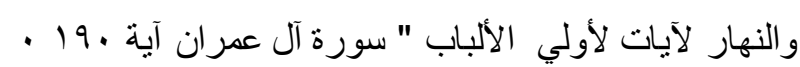
وقد وجدت بعض شواهد الدعاء والتسبيح في بعض فصول المقدمة :

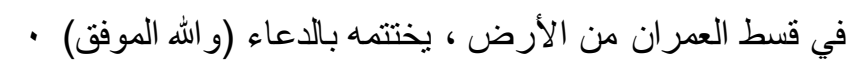

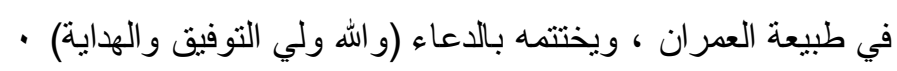

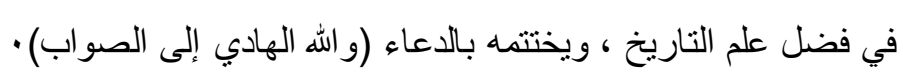

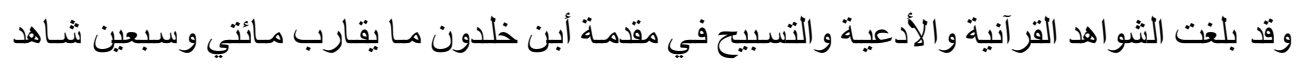

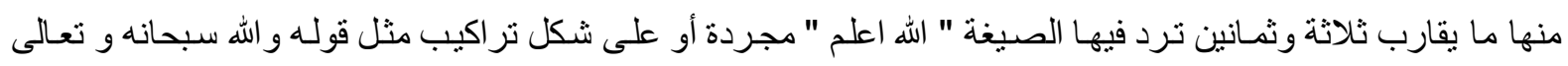

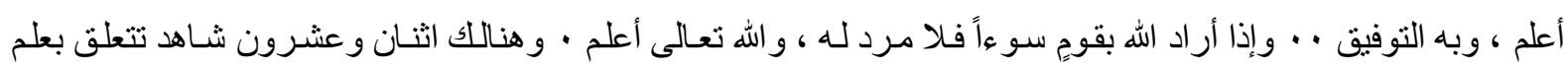

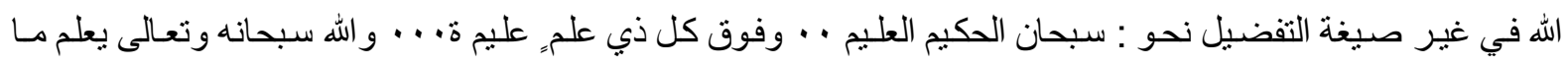


مما تقدم نستنتج إن أبن خلدون كان دووبا وحريصاً أن يختم كل فصل من فصول مقدمته بشو اهد قر آنية مستمدة قدر الإمكان من موضوع الفصل المخصوص بها . . . وكثير اً مـا تكون هذه الشواهد في نهايـات الفصول كقولـه و الله أعلم

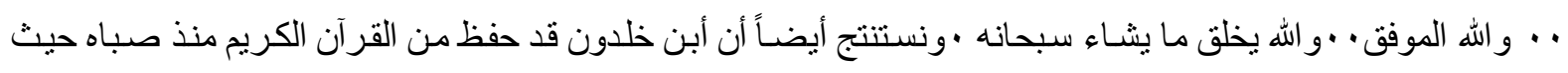
يقول : " وبعد أن استظهرت القرآن الكريم من حفظي ، قر أتهـ بـالقراءات السبع أفر اد وجمعا في إحدى و عشرين ختهـه ، ثم جمعتها في ختمه واحدة أخرى .

\section{الدولة واللك والباعة في الفكر الإسلاهي الفلدوني .}

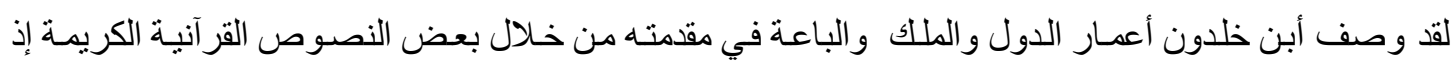

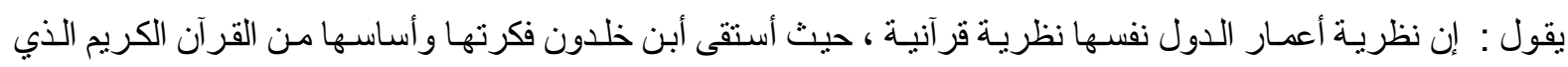

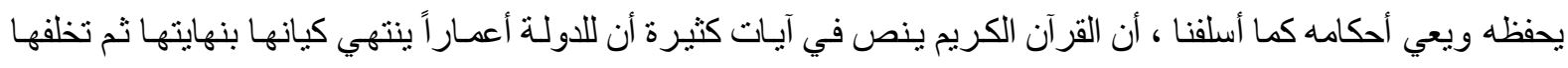

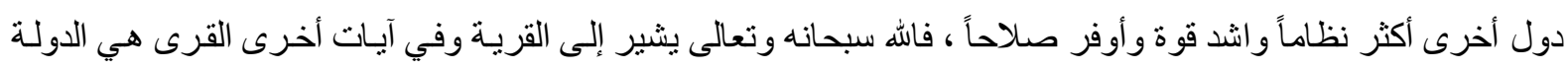

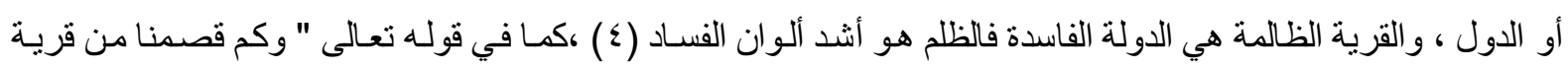

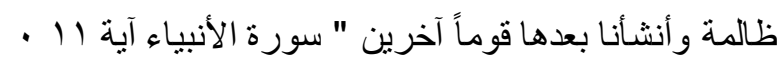

ويقرر أبن خلدون أن للدولة" أعماراً" كأعمار الأشخاص ، بمعنى إنه إذا كان لكل شخص عمر محدد تنتهي

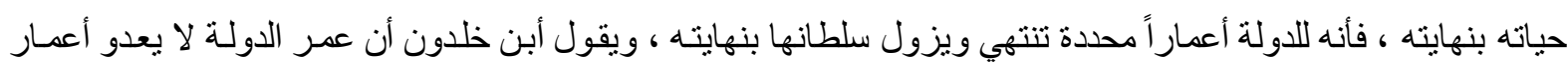

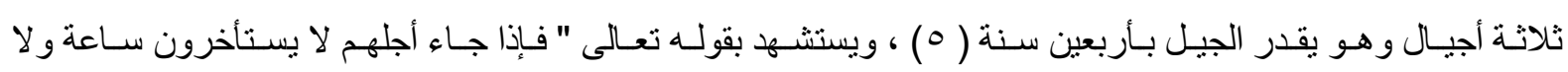

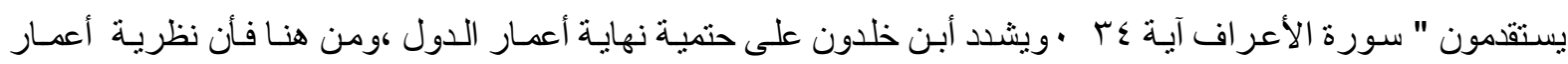

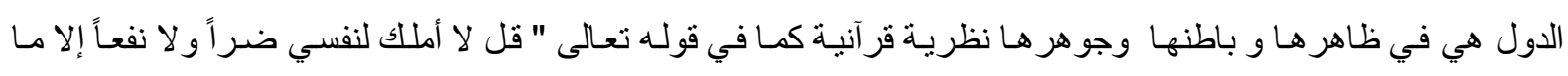

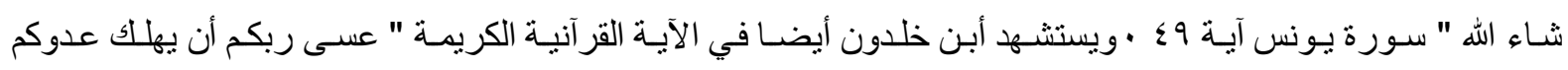

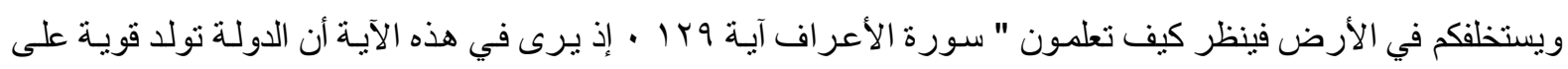

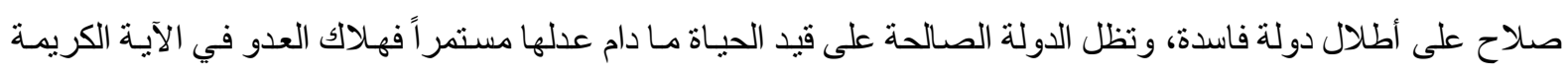

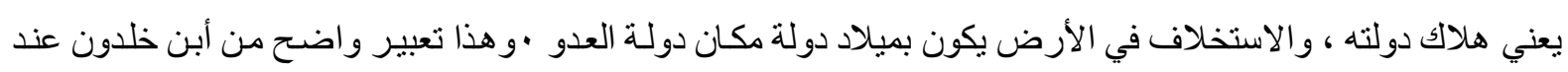

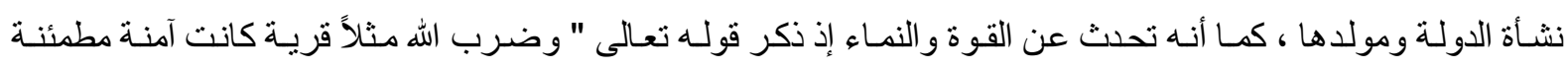

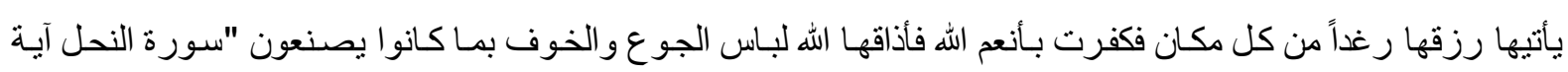

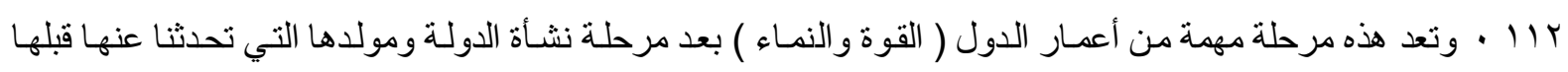

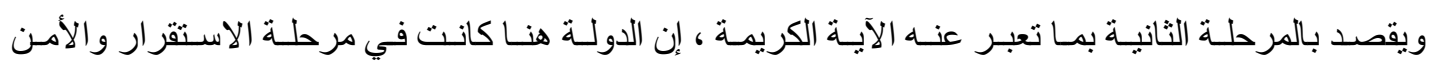

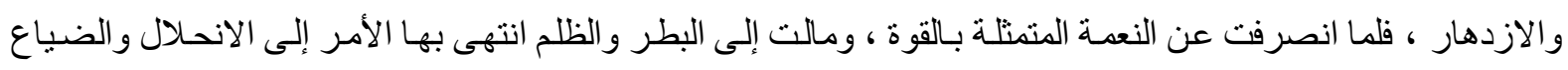

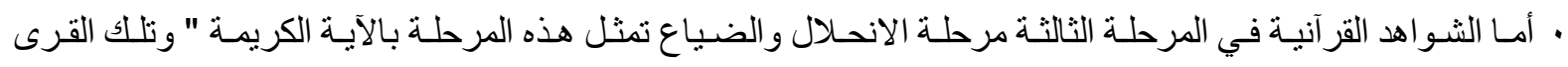

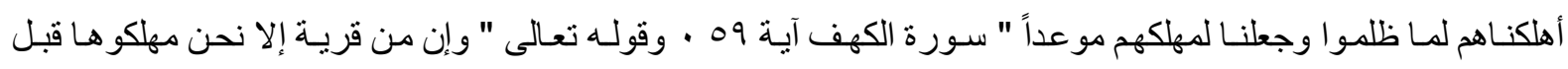

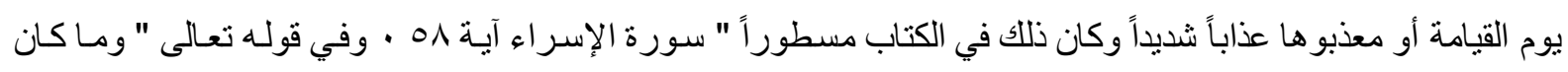

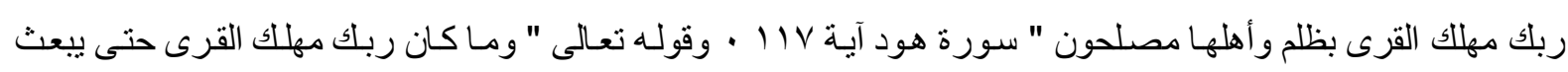

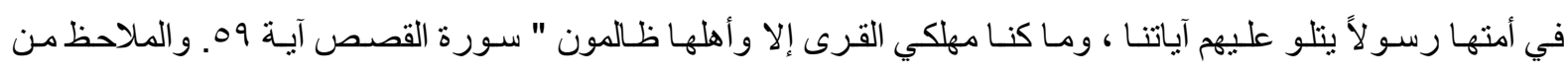

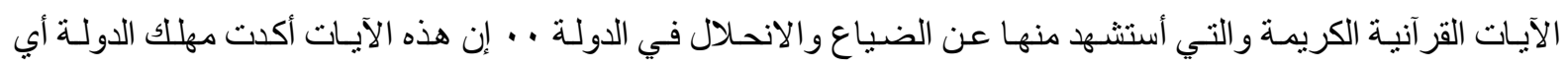


نهايتها ، وارتبط هلاكها ونهايتها بفسـادها في الأرض بـالظلم الذي يمارسـه حكامها ، وتتطرق هذه الآيات الكريمة إلى الى

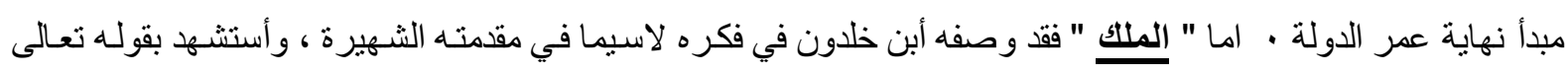

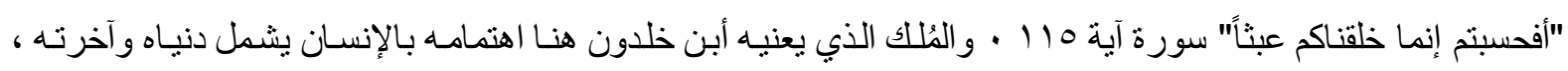
نلك أن القوانين التي تطبق على المجمع الإنسـاني يجب أن تكون إلهيـة، ونلك أن الخلق ليس المقصـود بهم دنياهم كلها

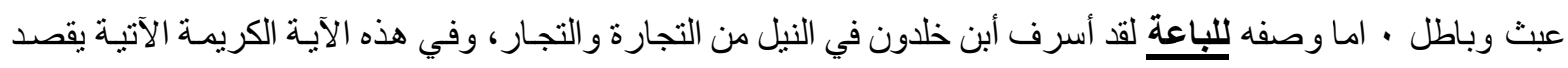

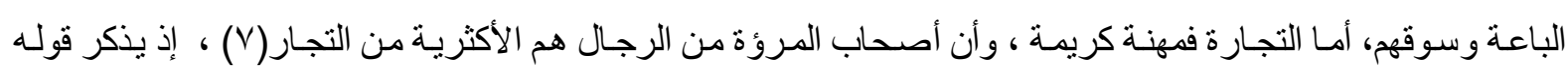

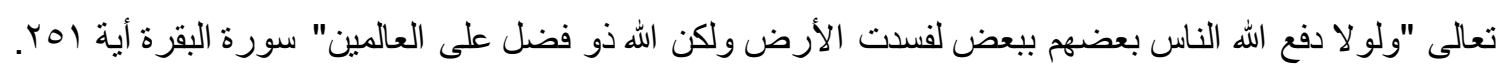
إذا نخلص مما تقدم في وصف الدولة والمُلك و الباعة أن رأس الدولة في العمران الخلدوني هو الأمسام أو الخليفة فأنها عنده وظيفة دينية سياسية اجتماعية ، وكل هذه الآراء تمثل عمق الفكر ودقة الاستقر اء و التي عبرت بشكل واضح عن عمق إيمان أبن خلدون بالله ... و الملاحظ عن مستهل حديثه في نظريته في العمران بعيد كل البعد عن المادية التي

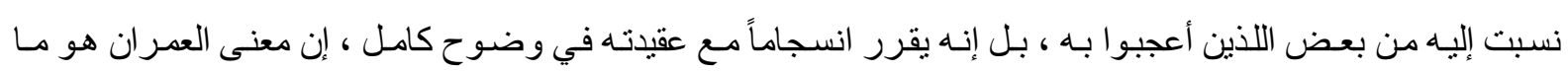

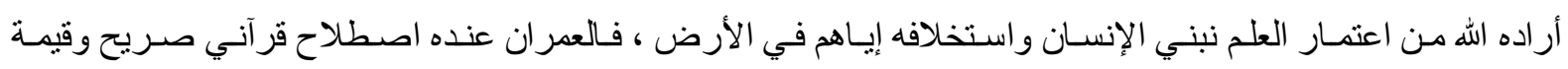
سلامية واضحة وهو استخلاف الله للإنسان في هذا الكوكب · باختصسار أن أبن خلدون فقيه أصولي مجتهد ، وهو أستاذ

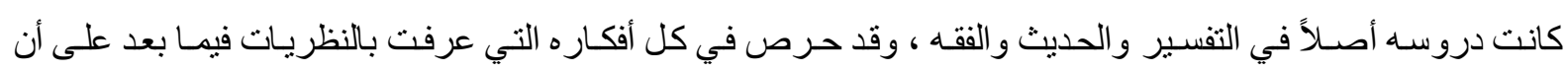
يدعم كل منهما بما يؤكد إسـاميتها بآية قرآنية أو حديث شريف أو عمل مأثور · ويمكن القول أن أبن خلدون نتاج بيئته

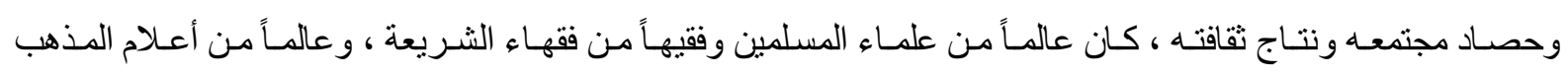

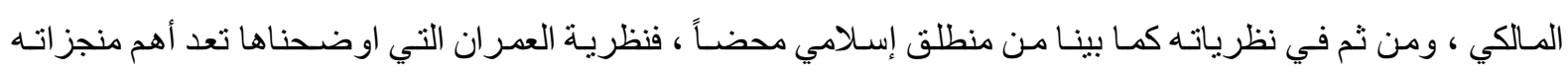

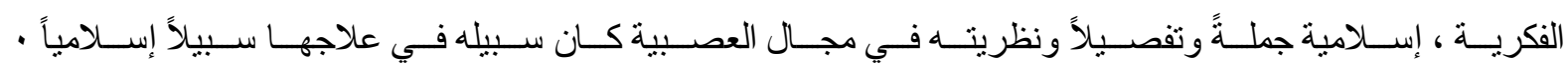
لقد أعتمد أبن خلدون الأسس الإسـلامية وهو يقدم نظرياتـه ، ونظسام الحكم الذي رآه مناسباً للعمران وهو وهو نظـام الخلافـة

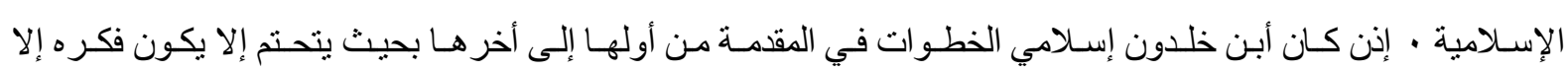
إسلامياً ، و هو مالم ينتبه إليه دارسوا الفكر الخلدوني . . . وهو بهذا مؤسس علم الاجتماع الإسلامي.

\section{القرآن الكريم ونظرية ابن خلدون الاجتماعية.}

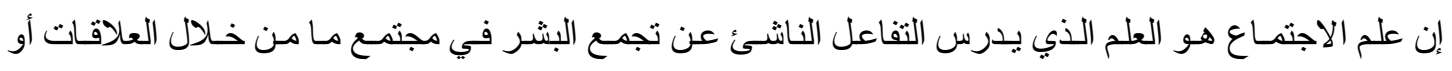
الظواهر و الواقع الاجتماعي في أطار منهج علمي وموضوعي يعبر عما هو كائن • فالقرآن الكريم يذكر العديد من أمنلة

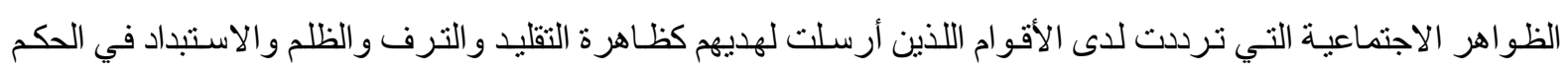
و الإجر ام وعبادة الأوثان و الكو اكب وتقديس الحيوان من الملائكة والجن وو أد البنـات واحتقار المر أة واستغلال المستخلين اللذين يأكلون أموال النـاس بالباطل وإلى ظهور الطبقية (طبقة رجال الدين ، طبقة المتكبرين ، وطبقة الضعفاء) . و أفاد

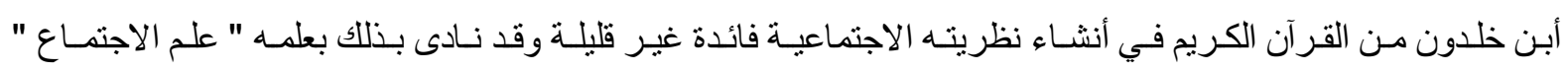

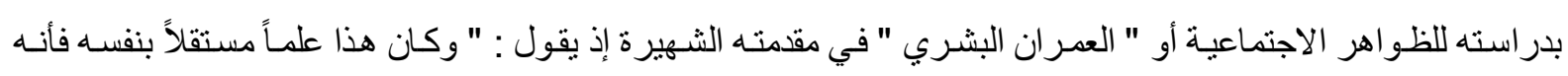

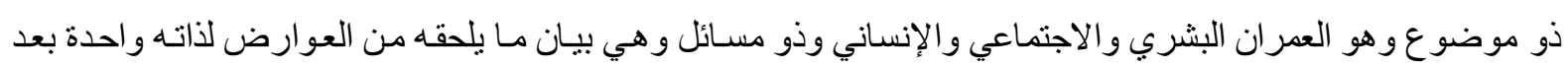

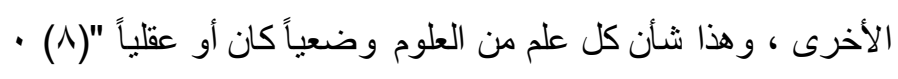

ومن الظوا هر الاجتماعية التي وصفها القرآن الكريم والتي يثبر إليها في المقدمة " ذم الترف " وتبيان أثره

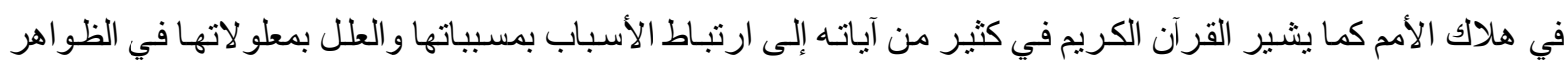

\section{-r. 9 -}


الاجتماعيـة من خـلال أحو ال الأقوام الغـابرة والأمم السـالفة ارتباطـاً عمـا يسميه العلهـاء المحدثون بالقانون أو النظريـة أو التعميم · وقد ذكر في " القرآن الكريم " ذم الترف " لكي يحذر النـاس من عو اقبهـ السيئة في دينهم ودنيـاهم ، أمسا أين

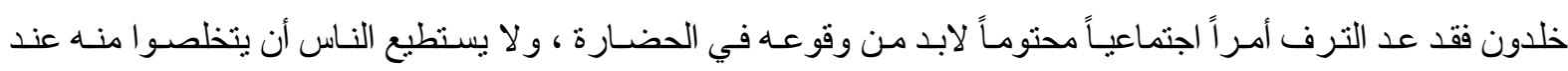
التحضير إذ هو يكون جزء من عاداتهم ، والعادات عند أبن خلدون قاسرة (9) ·

\section{الظواهر الاجتماعية والقرآن الكريم ومقدهة ابن خلدون.}

لقد ورنت في القرآن الكريم آيات كثيرة في هذا الثأن أنشار إليها أبن خلدون في مقدمته بمكن إجمالها بالآتي:

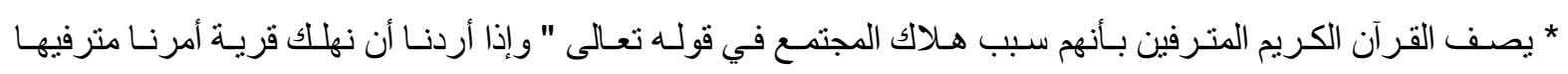

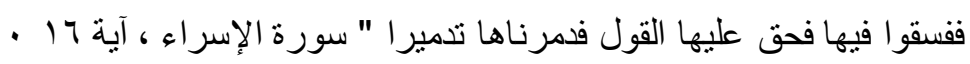

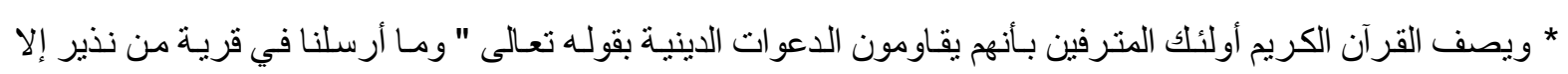

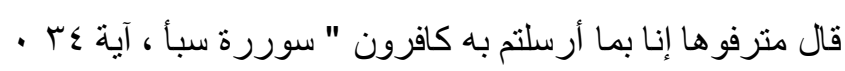
* ثم يصفهم بأنهم متعصبون لعقائد أبائهم ، حسنة كانت أم سيئة وذلك بقوله تعالى " وكنلك مـا أرسلنا من قبلك في قريـة

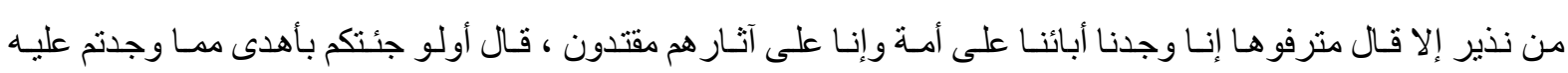

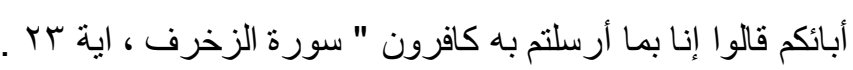

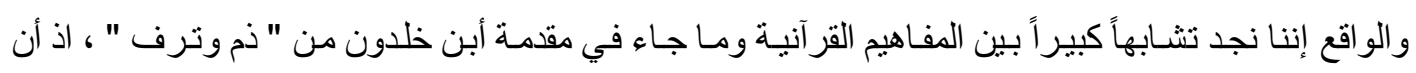

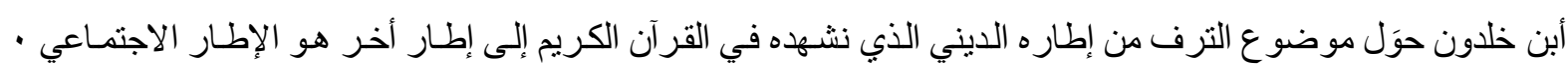

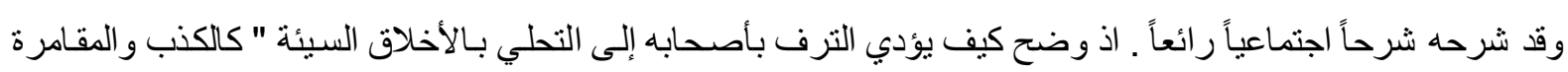

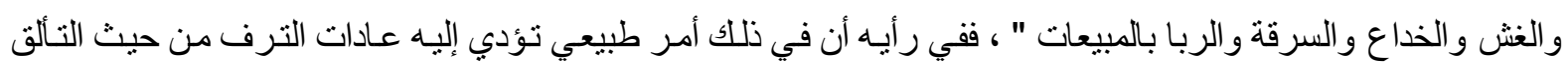

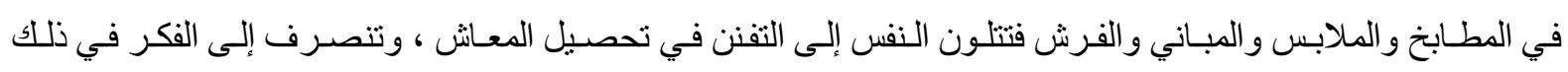

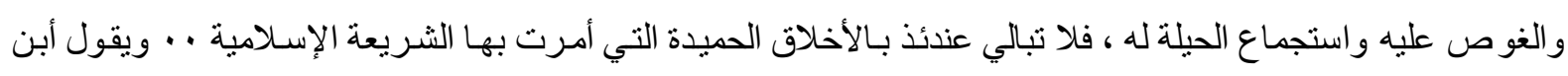

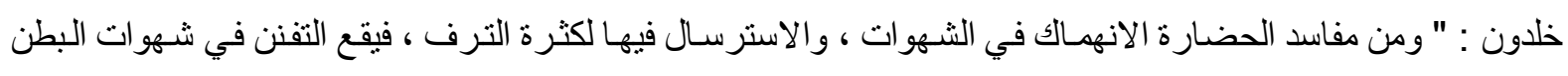

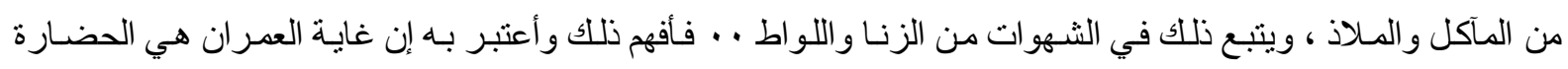
و الترف وإنه إذا بلغ غايته انقلب إلى الفساد وأخذ في الهرم كالأعمار الطبيعية للحيوانات " . ل

ومن طر ائف ما جاء به أبن خلدون في هذا الصدد انتقاده لفكرة كانت شـائعة بين الناس في زمانه ، إذ كانوا

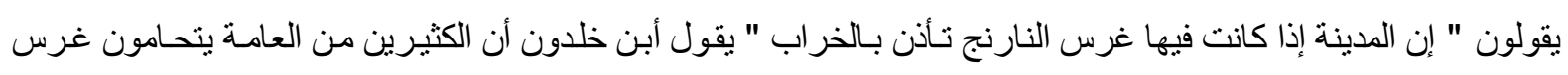

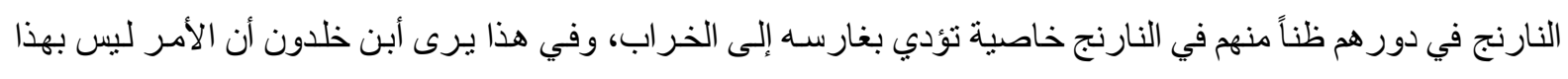

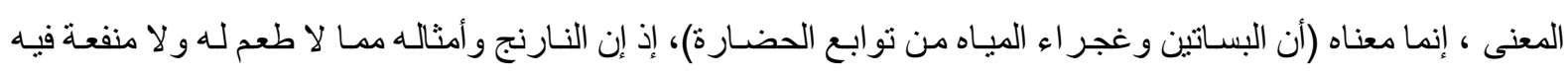

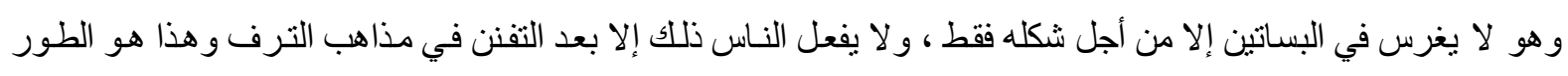

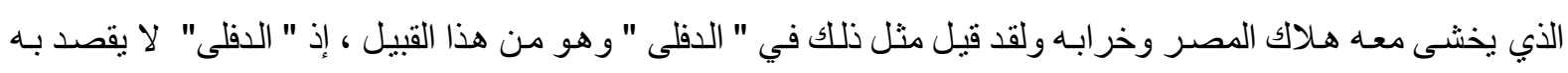

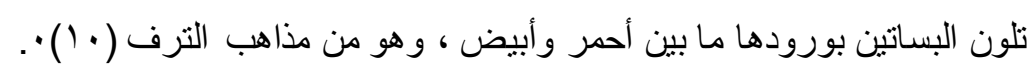
ويعتقد أبن خلدون أن " الترف " يزيد الدولة في أولها قوة والسبب في ذلك أن القبائل أذا حصل لهم الملك

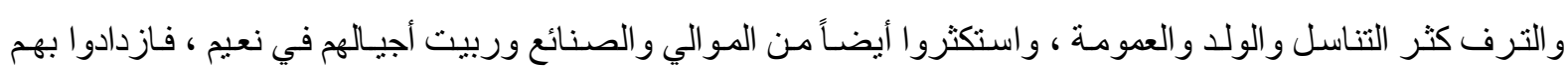


عدداً إلى عددهم ، وقوة إلى قوتهم ، بسبب كثرة العصـائب حينئذ بكثرة العدد ، فإذا ذهب الجيل الأول والثاني ، وأخذت

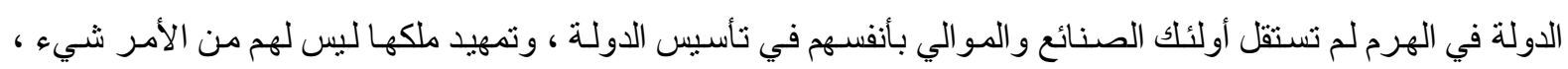

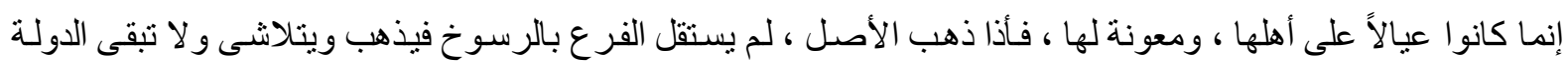

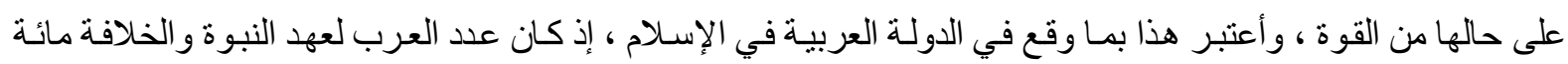

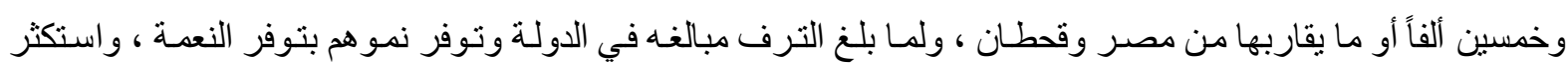

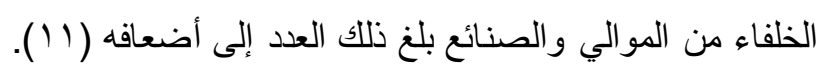

ومن هنا يمكن القول، إن الظواهر الاجتماعية ترنبط بـالقرآن الكريم ارتباطاً وثيقاً لمـا لها من تأثير على الأفراد

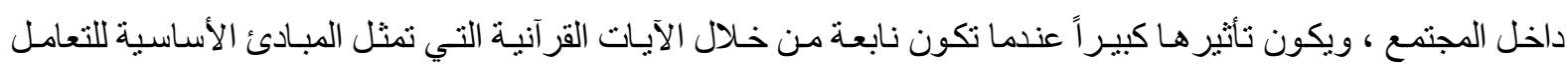

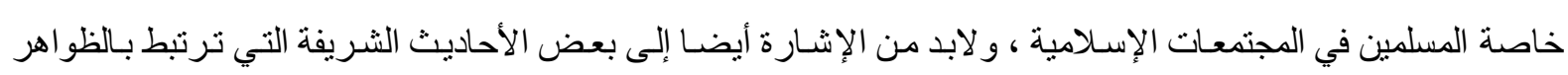

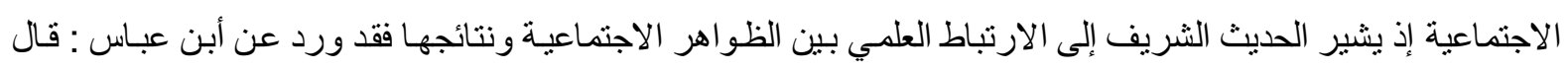

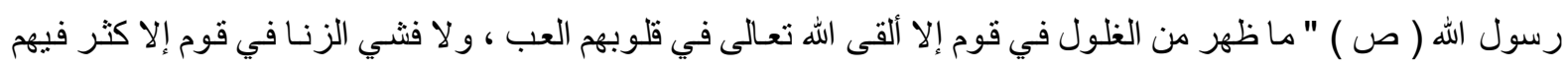

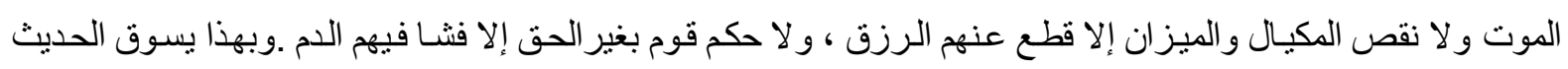

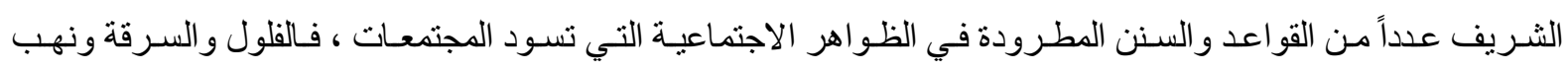

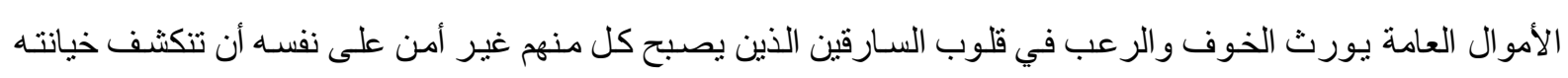

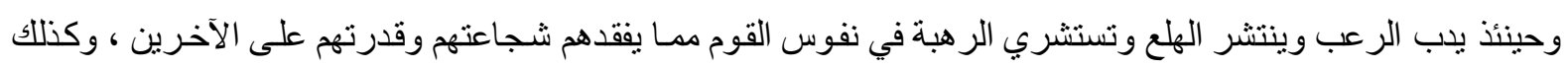

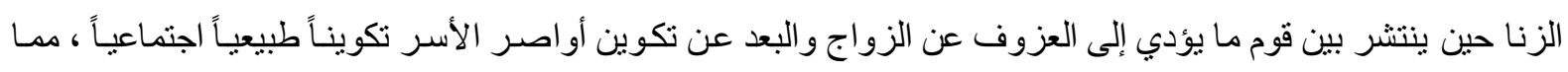

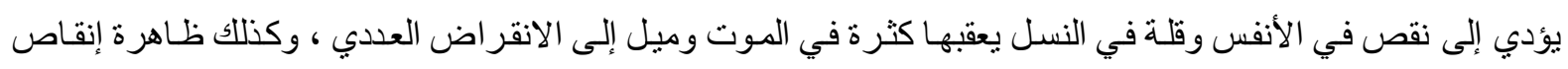

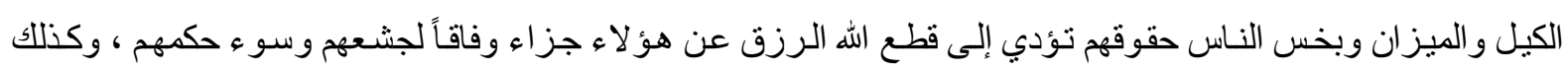

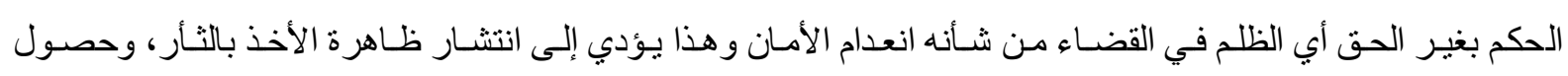

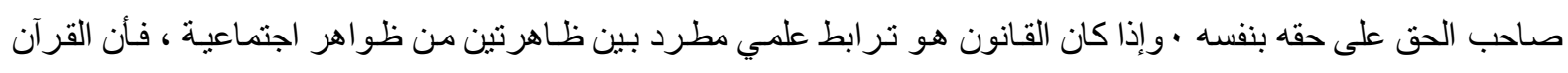

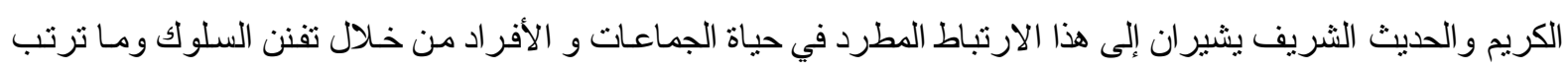

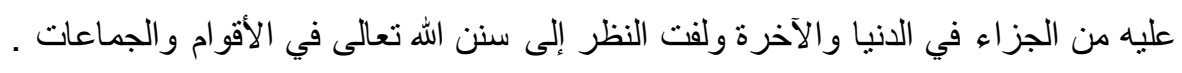

وأكد أبن خلدون من خـلال عملية الربط بين الظواهر الاجتماعية من جهة والقرآن الكريم من جهة أخرى في إني

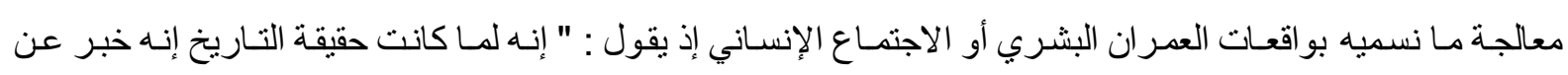

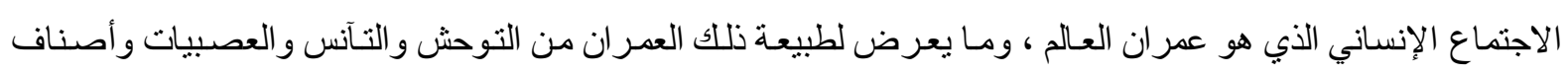

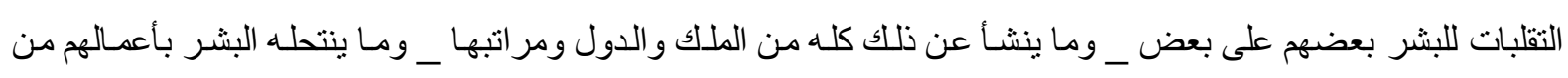

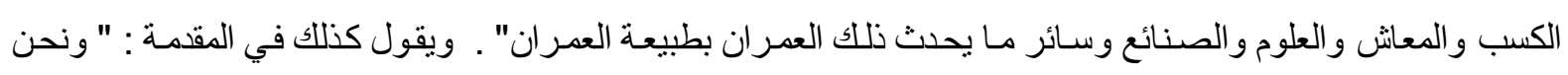

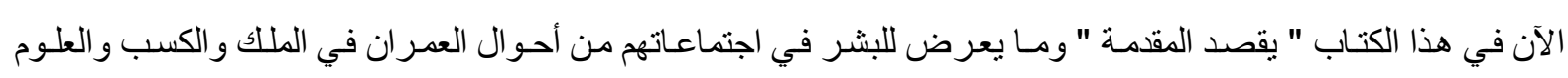

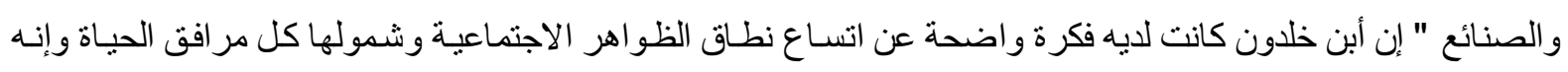

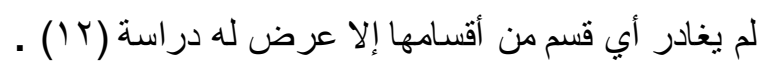

يتضح مما تقدم لقد توصل أبن خلدون إلى أهم القوانين في مجال الفكر الاجتمـاعي إلا وهي قوانين الحركة

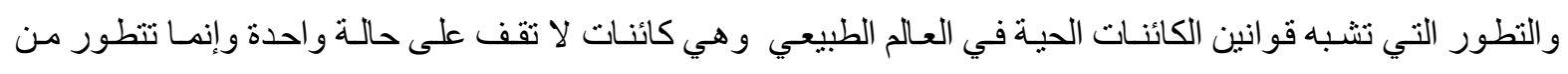

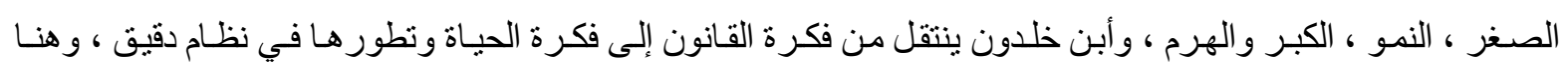


تأخذ نظريته شكلاً حيوياً بايلوجياً يقارن فيه المجتمع وحياته بالجسم الحي وحياته ، وفي هذا يسبق (أوجست كومت) من

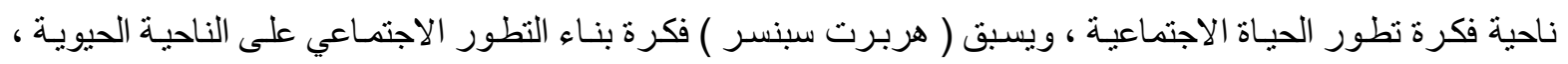

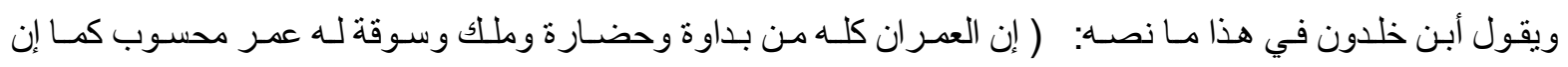

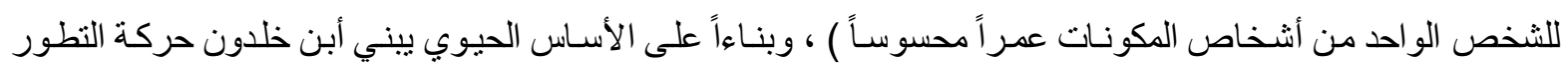

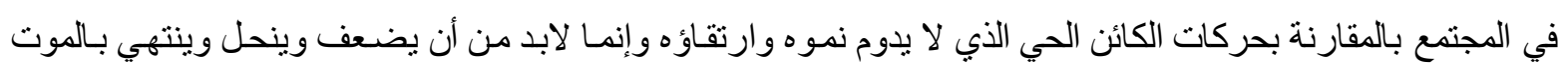

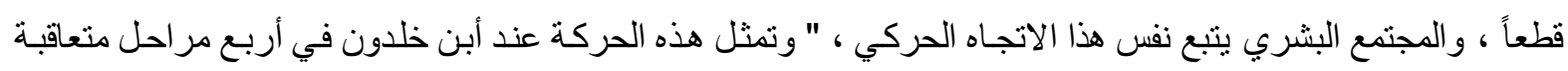

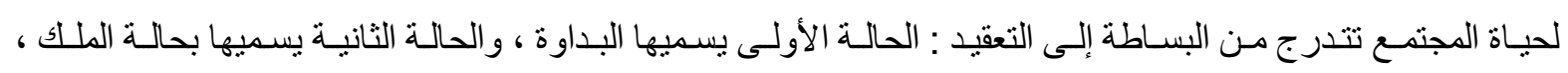

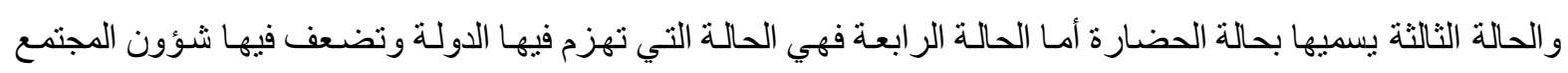

$$
\text { ويسميها بحالة الاضمحلال والخراب " (ب ال). }
$$

ولعلنا نلاحظ أن أبن خلدون وهو في مستهل حديثه عن نظريته في العمران بعيد كل البعد عن المادية التي

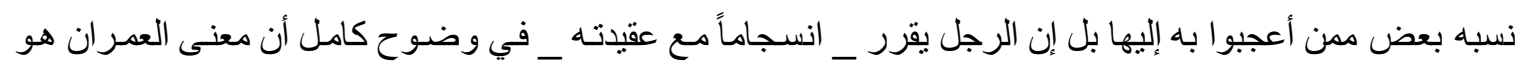

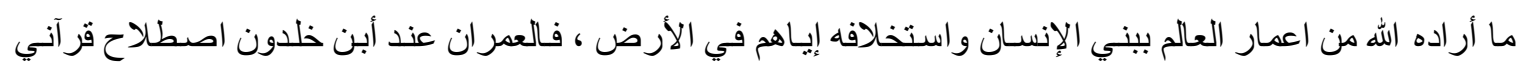

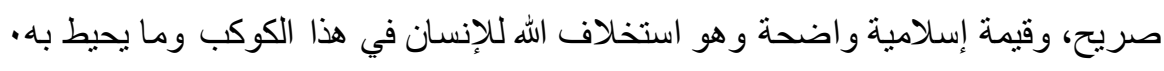

\section{هصادر البمث وهواهشه

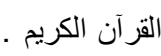 \\ الحديث النبوي الثريف.}

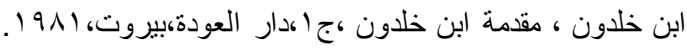

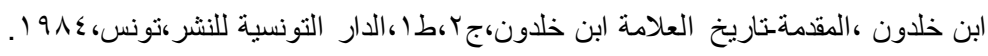

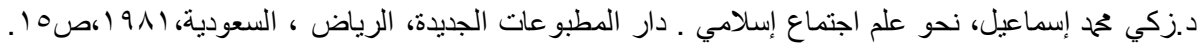

$-1$

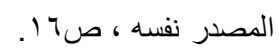

$-r$

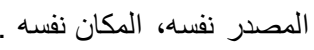

$-1$

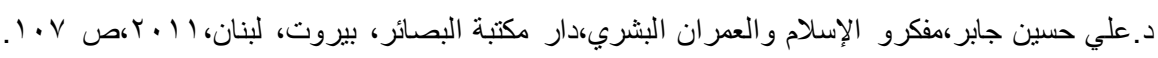

$-\varepsilon$

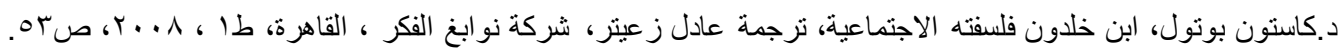

$-0$

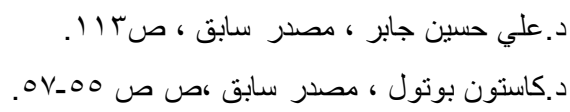

$-7$

$-\mathrm{V}$

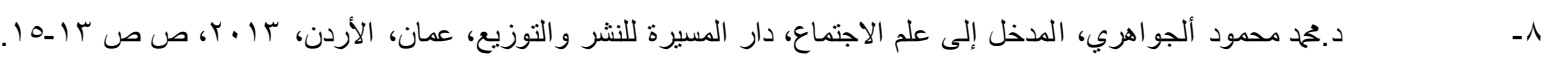

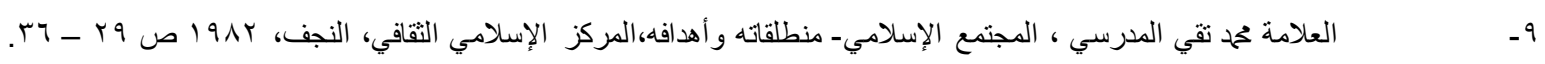

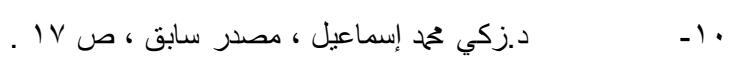

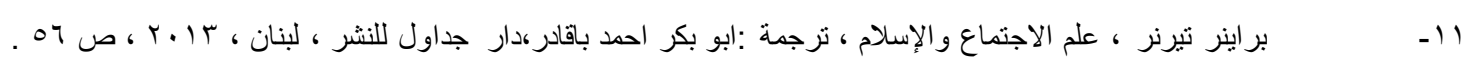

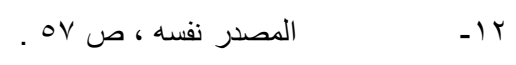

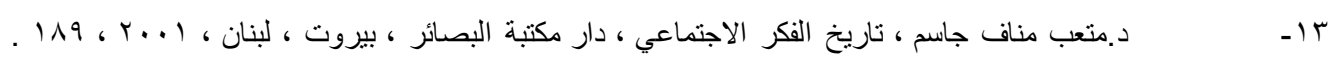

